\title{
FABP7 expression in normal and stab-injured brain cortex and its role in astrocyte proliferation
}

\author{
Kazem Sharifi • Yusuke Morihiro • Motoko Maekawa $\cdot$ Yuki Yasumoto • \\ Hisae Hoshi • Yasuhiro Adachi · Tomoo Sawada • Nobuko Tokuda • \\ Hisatake Kondo $\cdot$ Takeo Yoshikawa $\cdot$ Michiyasu Suzuki $\cdot$ Yuji Owada
}

Accepted: 5 September 2011 / Published online: 22 September 2011

(C) The Author(s) 2011. This article is published with open access at Springerlink.com

\begin{abstract}
Reactive gliosis, in which astrocytes as well as other types of glial cells undergo massive proliferation, is a common hallmark of all brain pathologies. Brain-type fatty acid-binding protein (FABP7) is abundantly expressed in neural stem cells and astrocytes of developing brain, suggesting its role in differentiation and/or proliferation of glial cells through regulation of lipid metabolism and/or signaling. However, the role of FABP7 in proliferation of glial cells during reactive gliosis is unknown. In this study, we examined the expression of FABP7 in mouse cortical stab injury model and also the phenotype of FABP7-KO mice in glial cell proliferation. Western blotting showed
\end{abstract}

Electronic supplementary material The online version of this article (doi:10.1007/s00418-011-0865-4) contains supplementary material, which is available to authorized users.

K. Sharifi · Y. Morihiro · Y. Yasumoto · Y. Adachi .

T. Sawada $\cdot$ N. Tokuda $\cdot$ Y. Owada $(\bowtie)$

Department of Organ Anatomy, Yamaguchi University Graduate

School of Medicine, 1-1-1 Minami-Kogushi,

Ube 755-8505, Japan

e-mail: yowada@yamaguchi-u.ac.jp

Y. Morihiro · M. Suzuki

Department of Neurosurgery, Yamaguchi University Graduate

School of Medicine, Ube, Japan

M. Maekawa · T. Yoshikawa

Department of Molecular Psychiatry, RIKEN Brain Science

Institute, Wako, Japan

H. Hoshi

Frontier Corporations, Sendai, Japan

H. Kondo

Division of Histology, Department of Rehabilitation,

Faculty of Health Science and Welfare,

Tohoku Bunka Gakuen University, Sendai, Japan that FABP7 expression was increased significantly in the injured cortex compared with the contralateral side. By immunohistochemistry, FABP7 was localized to $\mathrm{GFAP}^{+}$ astrocytes $\left(21 \%\right.$ of $\mathrm{FABP}^{+}$cells) and $\mathrm{NG}^{+}$oligodendrocyte progenitor cells $(62 \%)$ in the normal cortex. In the injured cortex there was no change in the population of $\mathrm{FABP}^{+} / \mathrm{NG}^{+}$cells, while there was a significant increase in $\mathrm{FABP}^{+} / \mathrm{GFAP}^{+}$cells. In the stab-injured cortex of FABP7-KO mice there was decrease in the total number of reactive astrocytes and in the number of $\mathrm{BrdU}^{+}$astrocytes compared with wild-type mice. Primary cultured astrocytes from FABP7-KO mice also showed a significant decrease in proliferation and omega-3 fatty acid incorporation compared with wild-type astrocytes. Overall, these data suggest that FABP7 is involved in the proliferation of astrocytes by controlling cellular fatty acid homeostasis.

Keywords FABP7 - Astrocyte - Oligodendrocyte progenitor cell $\cdot$ Reactive gliosis $\cdot$ Brain injury

\section{Introduction}

Polyunsaturated fatty acids (PUFAs) have important metabolic, structural and signal transducing roles. PUFAs are abundant in the developing brain and are essential for normal development of the brain. Several studies have suggested a negative correlation between dietary consumption of PUFAs and risk of several neuropsychiatric diseases such as multiple sclerosis (Esparza et al. 1995; Lauer 1994; Swank et al. 1952), Parkinson disease (de Lau et al. 2005), Alzheimer disease (Barberger-Gateau et al. 2002; Morris et al. 2003), schizophrenia (Fedorova et al. 2009; Amminger et al. 2010), depression, other psychotic and mood disorders and developmental disorders like 
ADHD and autism (Muskiet and Kemperman 2006; Hedelin et al. 2010). Therapeutic effects of PUFAs have also been suggested even in these diseases, and PUFA supplements are currently recommended to these patients as alternative or complementary medicine (Peet et al. 2001; Nordvik et al. 2000; Weinstock-Guttman et al. 2005). Nevertheless, there is limited evidence to support preventive and therapeutic effects of PUFAs (Ross et al. 2007; Mehta et al. 2009).

Fatty acid-binding proteins (FABPs) are intracellular low-molecular-weight (14-15 kDa) polypeptides and are key molecules in the uptake, transportation and storage of long-chain fatty acids and in mediating their signal transduction and gene regulation activities. Twelve members of the FABP family have been recognized so far, which are differentially expressed in different organs, tissues and cell types. FABP7 (brain-type FABP), a strong binder of omega-3 PUFAs, is abundantly expressed in neural stem cells and astrocytes of the developing brain, suggesting a role in glial cell differentiation and proliferation of glial cells (Owada et al. 1996; Maekawa et al. 2011). However, the functional significance of FABP7 expression in cortical astrocytes under normal and pathological conditions remains unknown.

Reactive gliosis, whereby astrocytes and other types of glial cells undergo massive proliferation, is a common hallmark of numerous brain pathologies. However, the underlying mechanisms of gliosis are largely unknown. Reactive gliosis consists of a range of molecular and morphological changes, especially in astrocytes, including cellular hypertrophy, alteration in molecular expression, proliferation and scar formation. Recently, it was reported that docosahexaenoic acid (DHA), a ligand of FABP7, prevents degradation of neurons and astrocytes following brain ischemia and spinal cord injury by protection of neurons and astrocytes from cell degeneration (Belayev et al. 2011), suggesting a role for FABP7 in regulating CNS injury. Furthermore, there is an association of FABP7 with poor prognosis of malignant glioma (Godbout et al. 1998; Tso et al. 2006; Liang et al. 2005; Kaloshi et al. 2007), providing support for a role of FABP7 in astrocytes responses to injury. FABP7 is also abundantly expressed in neural stem cells and plays a role in maintenance of neuroepithelial cells during early developmental stages (Arai et al. 2005), and as such, may be important in adult neural cell progenitors, which share some characteristics of neural stem cells .

In the present study, we examined the detailed localization of FABP7 in the normal and stab-injured brain cortex of adult mice and determined its role in astrocyte proliferation in vivo and in vitro using FABP7 knockout (KO) mice (Owada et al. 2006). We found that FABP7 regulated the proliferative response of astrocytes to injury.
Furthermore, we observed novel expression of FABP7 in oligodendrocyte progenitor cells (OPCs).

\section{Materials and methods}

Animals

Three-month-old male C57BL/6 mice (14 wild-type and 14 FABP7-KO) (Owada et al. 2006) were used for brain cortex stab injury experiments. All experimental protocols were reviewed by the Ethics Committee for Animal Experimentation of Yamaguchi University School of Medicine and were performed according to the Guidelines for Animal Experimentation of the Yamaguchi University School of Medicine and Under Law and Notification requirements of the Japanese Government.

\section{Stab injury model}

Animals were anesthetized (Isoflurane; Abbott, IL, USA) using a small animal anesthetizer (Muromachi Co., Tokyo, Japan) and a 1-mm-deep stab wound was made on the right cerebral neocortex (Bregma, -1 to $-2.5 \mathrm{~mm}$. Latero-lateral, 1.5-2.5 mm) (Buffo et al. 2005) (see Supplementary Fig. 1a, e). Mice were killed at 3 ( $n=7$ for wild-type mice, $n=7$ for FABP7-KO mice) and $7(n=7)$ days post lesion (DPL).

\section{Cell culture}

For primary cultured astrocytes, the cerebral cortices of newborn mice (wild-type and FABP7-KO) were dissected, and the meninges were carefully removed. Tissues were cut into small pieces in HBSS (Hanks buffer salt solution) supplemented with glucose, penicillin and streptomycin and further dissociated by trypsin treatment $(0.25 \%)$ at $37^{\circ} \mathrm{C}$ for $20 \mathrm{~min}$. Debris was removed by filtering through a $100-\mu \mathrm{m}$ mesh, and the cell suspension was centrifuged at $1,000 \mathrm{rpm}$ and $20^{\circ} \mathrm{C}$ for $5 \mathrm{~min}$. The supernatant was removed and the pellet was resuspended in DMEM supplemented with $10 \%$ FBS, penicillin, streptomycin and amphotericin $\mathrm{B}$ and then seeded at a density of $2 \times 10^{6}$ cells per T25 flask. Cells were incubated in a $5 \% \mathrm{CO}_{2}$ incubator at $37^{\circ} \mathrm{C}$ until cells became confluent. The culture flasks were shaken on an orbital shaker (BR-40LF; TAITEC, Koshigaya, Japan) at $200 \mathrm{rpm}$ and $37^{\circ} \mathrm{C}$ for more than $14 \mathrm{~h}$ to detach loosely attached microglia and OPCs from the astrocytic bed. Immediately after shaking, the cells were washed three times with PBS and culture medium was refreshed. After 2-day incubation in $5 \% \mathrm{CO}_{2}$ at $37^{\circ} \mathrm{C}$, flasks were washed with PBS for three times and treated with trypsin/EDTA/PBS for $5 \mathrm{~min}$ at $37^{\circ} \mathrm{C}$. The 
purity of astrocytes was confirmed to be $>95 \%$ by GFAP immunostaining.

OPC culture was performed as described before (Nishiyama et al. 2010). OPCs in mixed cortical glial cultures (primary culture) and isolated OPCs in the presence of PDGF AA (secondary culture) were characterized immnunocytochemically by NG2 or PDGFR $\alpha$ expression.

For establishment of FABP7 stably over-expressing cells, the coding region of mouse FABP7 gene was amplified by PCR and sub-cloned into the pcDNA3 mammalian expression vector. The constructed expression vector (pcDNA3 for mock, pcDNA3/FABP7) was transfected into NG108 cells (rodent neuroblastoma/glioma hybrid cells; a kind gift from Dr. K Fukunaga, Tohoku University) using Lipofectamine 2000 (Invitrogen Co., Carlsbad, CA, USA) following the manufacturer's instructions, and the cells were selected for 2 weeks in culture media supplemented with $0.5 \mathrm{mg} / \mathrm{ml} \mathrm{G} 418$ (SigmaAldrich, St. Louis, MO, USA). The resistant clones were harvested, and the over-expression of the gene and protein was confirmed by RT-PCR and Western blot analysis, respectively.

\section{Immunohistochemistry}

Animals were transcardially perfused with 4\% paraformaldehyde (PFA) in $0.1 \mathrm{M}$ sodium phosphate buffer $(\mathrm{pH}$ 7.4). Brains were removed, postfixed in 4\% PFA (at least for $4 \mathrm{~h}$ ) and cryoprotected with graded sucrose (10, 20 and $30 \%$; each for approximately $10 \mathrm{~h}$ ) at $4^{\circ} \mathrm{C}$ then stored at $-80^{\circ} \mathrm{C}$. Brain samples were cut into serial coronal $12-$ to $14-\mu \mathrm{m}$-thick sections with 50 - to $60-\mu \mathrm{m}$ intervals using a cryostat (Leica CM1850; Leica, Nussloch, Germany) and then mounted onto glass slides. Sections were rehydrated in PBS containing $0.01 \%$ Tween 20 (TPBS) for $10 \mathrm{~min}$, permeabilized with $0.3 \%$ triton $\mathrm{X}-100$ in PBS for $30 \mathrm{~min}$, washed three times in TPBS over $15 \mathrm{~min}$ and then blocked in 5\% skim milk in TPBS as blocking solution for $1 \mathrm{~h}$ at room temperature. When using the antibody of mouse origin, we used M.O.M Kit (Vector Laboratories, Burlingame, CA, USA) for masking the endogenous Fc receptors. Sections were incubated in combinations of the following primary antibodies for $16 \mathrm{~h}$ at $4{ }^{\circ} \mathrm{C}$ : rabbit antiFABP7 $(0.5 \mu \mathrm{g} / \mathrm{ml})$ (Abdelwahab et al. 2003), rabbit antiNG2, guinea pig anti-NG2 and rabbit anti-PDGFR- $\alpha$ (1:1000, 1:50 and 1:1000, respectively, kindly provided by W. Stallcup, Burnham Institute, http://www.burnham.org), rat anti-GFAP (1:200, Invitrogen), mouse anti-NeuN (1:100, Millipore, Billerica, MA, USA), mouse anti-MAP2 (1:500, Sigma-Aldrich), rat anti-CD11b (1:50, Chemicon, Temecula, CA, USA), mouse anti-BrdU (1:100, BD Pharmingens, San Diego, CA, USA) (see Supplementary Table 1).
After primary antibody incubation, sections were washed three times in TPBS for 30 min and incubated with combinations of the following secondary antibodies for $30 \mathrm{~min}$ at room temperature: anti-rabbit IgG-Alexa488, anti-rabbit IgG-Alexa 633, anti-mouse IgG-Alexa568, antirat IgG-Alexa 568, and anti-guinea pig IgG-Alexa 555 (1:1000 for all; Invitrogen Co.). 4',6-Diamidino-2-phenylindole (DAPI) $(0.5 \mu \mathrm{g} / \mathrm{ml}$, Invitrogen Co.) was added as a nuclear marker. When required, Zenon rabbit IgG labeling reagents (Molecular Probes, Invitrogen Co.) labeled with Alexa Fluor 594 and Alexa Fluor 488 were used for double-staining of rabbit primary antibodies. Slides were cover-slipped using Fluoromount (DBS, CA, USA). For negative controls of the antibodies used in this study, we omitted the primary antibody reaction in the immunohistochemical procedure and confirmed the absence of the reaction under such condition. Furthermore, for FABP7 antibody, the authenticity was confirmed by the complete absence of the reaction in FABP7-KO mouse tissues/cells.

\section{BrdU uptake assay}

For proliferation assay after stab injury, single intraperitoneal injection $(100 \mathrm{mg} / \mathrm{kg})$ of Brdu (Sigma-Aldrich) was performed at 3 days after lesion (DPL3), and animals were killed after $2 \mathrm{~h}$ ( $n=4$ for wild-type, $n=4$ for FABP7-KO mice) or 4 days after injection (DPL7: $n=4$ for wild-type, $n=4$ for FABP7-KO mice) (White et al. 2010). For cultured astrocytes, BrdU $(10 \mu \mathrm{M})$ was added to culture medium at 3 days after seeding when the astrocytes reached a subconfluent state, and was incubated for $5 \mathrm{~h}$. $\mathrm{BrdU}^{+}$cells were visualized immunocytochemically using an anti-BrdU antibody as described previously with slight modifications (White et al. 2010; Yang et al. 2009). Briefly, cells were incubated with $2 \mathrm{M} \mathrm{HCl}$ at room temperature for $30 \mathrm{~min}$ followed by washing twice with $0.1 \mathrm{M}$ sodium borate $(\mathrm{pH} 8.5)$ over $10 \mathrm{~min}$. After blocking with $5 \%$ goat serum at room temperature for $30 \mathrm{~min}$, they were incubated with mouse anti-BrdU antibody $(1: 100)$ at $4{ }^{\circ} \mathrm{C}$ overnight, and incubated with anti-mouse IgG-Alexa568 (1:1000) at room temperature for $1 \mathrm{~h}$ and then counterstained with DAPI. After several washes with PBS, they were mounted and cover slipped. Brain sections were pretreated by microwave heating in citrate buffer $(\mathrm{pH} 6)$ at $96^{\circ} \mathrm{C}$ for $10 \mathrm{~min}$ followed by incubation in $2 \mathrm{~N} \mathrm{HCl}$ at $37^{\circ} \mathrm{C}$ for $11 \mathrm{~min}$ and stained as described above.

Morphometric analysis

Sections were observed by a confocal laser scanning microscope (LSM510 META; Carl Zeiss, Oberkochen, Germany) and images were obtained in a $0.1 \mathrm{~mm}^{2}$ area $(40 \times$ lens with 0.7 zoom, $317 \times 317 \mu \mathrm{m})$, approximately 
$0.1 \mathrm{~mm}$ either lateral or medial to the edge of the lesion in the gray matter of the cortex (mostly layers III and IV, where astrocyte population includes only protoplasmic astrocytes) (Nag 2011). Corresponding areas in the contralateral cortex were also imaged. For BrdU assessment, counts were performed in $0.4 \mathrm{~mm}^{2}$ areas $(20 \times$ lens with 0.7 zoom, $635 \times 635 \mu \mathrm{m}$ ) from the edge of the lesion in both the lateral and medial sides (see Supplementary Fig. 1b).

\section{Western blot analysis}

Mice were killed 3 days after stab injury. The ipsilateral cortex containing the stab injury and the corresponding contralateral cortex were dissected $(2 \times 2 \times 2 \mathrm{~mm}$ blocks). Whole tissue lysate was prepared in $2 \times$ SDSPAGE sample buffer containing protease inhibitors (Roche Diagnostics, Mannheim, Germany). The lysates were electrophoresed on a 15\% SDS-polyacrylamide gel and immunoblotted onto Immobilon-P ${ }^{\mathrm{SQ}}$ PVDF membrane (Millipore). After blocking with skim milk, membranes were incubated with rabbit anti-FABP7 antibody $(0.125 \mu \mathrm{g} / \mathrm{ml})$ (Abdelwahab et al. 2003) and mouse anti- $\beta$-actin antibody (1:5000, Santa Cruz Biotech, Santa Cruz, CA, USA) overnight at $4{ }^{\circ} \mathrm{C}$ followed by incubation with HRP-conjugated goat anti-rabbit antibody (1:1000, Chemicon) and goat antimouse antibody (1:1000, Chemicon). Detection of reactive bands was performed using the ECL kit (Amersham Pharmacia Biotech, Piscataway, NJ, USA).

\section{${ }^{3} \mathrm{H}$-thymidine incorporation assay}

Primary cultured astrocytes were incubated in 24-well plates at the subconfluent status. The cells were then incubated in fresh medium containing $10 \%$ fetal calf serum and ${ }^{3} \mathrm{H}$-thymidine $(1 \mu \mathrm{Ci}$ per well; Amersham, Piscataway, NJ, USA) for $24 \mathrm{~h}$ at $37^{\circ} \mathrm{C}$. After incubation, the cells were washed twice with $500 \mu \mathrm{l}$ of ice-cold PBS (0.1 M; pH 7.4), detached with trypsin-EDTA solution and collected on GF/C filters (Whatman, Clifton, NJ, USA). The filters were washed three times with $1 \mathrm{ml}$ of $10 \%$ trichloroacetic acid and rinsed twice with $1 \mathrm{ml}$ of absolute ethanol. The radioactivity contained on each filter was determined using a scintillation counter (LSC-5100; Aloca, Tokyo, Japan).

Fatty acid incorporation assay

Primary cultured astrocytes were incubated in 12-well plates. A $0.1 \mu \mathrm{Ci} / \mathrm{ml}$ of ${ }^{14} \mathrm{C}$-linoleic acid or ${ }^{14} \mathrm{C}$ - $\alpha$-linolenic acid (Amersham Pharmacia Biotech) was added to confluent cultured astrocytes. After incubation for 30-120 min, the cells were washed thoroughly with cold PBS and lysed with $0.1 \mathrm{M} \mathrm{NaOH}$. Radioactivity was measured using a $\beta$-scintillation counter. Radioactivity was normalized to the DNA content of the sample.

Cell titer assay

The cell titer was quantified using the CellTiter 96 Aqueous One Solution Cell Proliferation Assay (Promega, Madison, WI, USA) according to the manufacturer's manual. Briefly, after seeding the cells onto 96-well plates at the density of $1 \times 10^{4}$ cells/well, the coloring solution was added to the culture media at each time point $(0,1,2$, 3,4 and 5 days after seeding). Following incubation for $2 \mathrm{~h}$, chromogenic development was measured at $490 \mathrm{~nm}$ by spectrophotometer (Beckman Coulter, Fullerton, CA, USA). The experiment was done in quadruplicate and the mean value of optical density in each time point was calculated.

\section{Statistical analysis}

All data are shown as mean \pm SD. Statistical comparisons of means were made by Student's two-tailed unpaired $t$ test or, for multiple comparisons, one-way ANOVA followed by the Tukey test. $P$ values $<0.05$ were considered statistically significant.

\section{Results}

Localization of FABP7 in normal cortex

In the normal (intact) cortex, $\mathrm{FABP}^{+}$cells exhibiting several cellular processes were evenly scattered throughout the cortex. In these cells, FABP7 immunopositive staining was observed in the nuclei and cytoplasm (Fig. 1). The majority $(62.7 \pm 6.3 \%, n=3)$ of the $\mathrm{FABP}^{+}$cells were positive for NG2 proteoglycan, a marker for OPCs (termed polydendrocytes) (Nishiyama et al. 2009) (Fig. 1a, f). Confirmation of $\mathrm{FABP}^{+}$cells as OPCs was further performed by staining with PDGFR $\alpha$, a specific marker of OPCs (Zhu et al. 2010; Gao et al. 2010; Ozerdem et al. 2001; Nishiyama et al. 2009) (Fig. 1b). Furthermore, $97.1 \pm 2.5 \%$ of $\mathrm{NG}^{+}$OPCs in the intact cortex were $\mathrm{FABP}^{+}$(Fig. 1f). By contrast, $21.6 \pm 3.7 \%$ of $\mathrm{FABP}^{+}$ cells in the intact cortex were $\mathrm{GFAP}^{+}$astrocytes (Fig. 1c) and $82.4 \pm 10.6 \%$ of $\mathrm{GFAP}^{+}$astrocytes were $\mathrm{FABP}^{+}$. In the upper layers near the dorsal surface of the cortex where $\mathrm{GFAP}^{+}$cells exhibit a higher population density, thicker and less branched processes and more intensive expression of GFAP (also known as interlaminar astrocytes, Nag 2011), $\mathrm{GFAP}^{+}$astrocytes comprised near half of all $\mathrm{FABP}^{+}$cells, with the remainder being $\mathrm{NG}^{+}{ }^{+} \mathrm{OPCs}$ (data not shown). 
Fig. 1 Identification of FABP7 expressing cells in the normal adult cerebral cortex.

a-d Immunofluorescence micrographs showing expression of FABP7 in OPCs and astrocytes. a Expression of FABP7 (green) in $\mathrm{NG}^{+}$OPCs (red). b Expression of FABP7 in OPCs confirmed by colocalization of FABP7 (green) and PDGFR $\alpha$ (red). c Expression of FABP7 (green) in $\mathrm{GFAP}^{+}$protoplasmic astrocyte. d Localization of FABP7 (green) in $\mathrm{NG}^{+}$OPCs (red) and $\mathrm{GFAP}^{+}$astrocytes (blue). Note that the majority of FABP $7^{+}$cells are OPC. e Bar graph showing the percentage of $\mathrm{NG}^{+} \mathrm{OPCs}^{2}$ and $\mathrm{GFAP}^{+}$ astrocytes among total $\mathrm{FABP}^{+}$ cells. f Bar graph showing the percentage of $\mathrm{FABP}^{+}$cells in $\mathrm{NG}^{+}{ }^{+} \mathrm{OPCs}$ and $\mathrm{GFAP}^{+}$ astrocytes. Data in $\mathbf{e}, \mathbf{f}$ are obtained from $0.1 \mathrm{~mm}^{2}$ area. Scale bars $20 \mu \mathrm{m}$
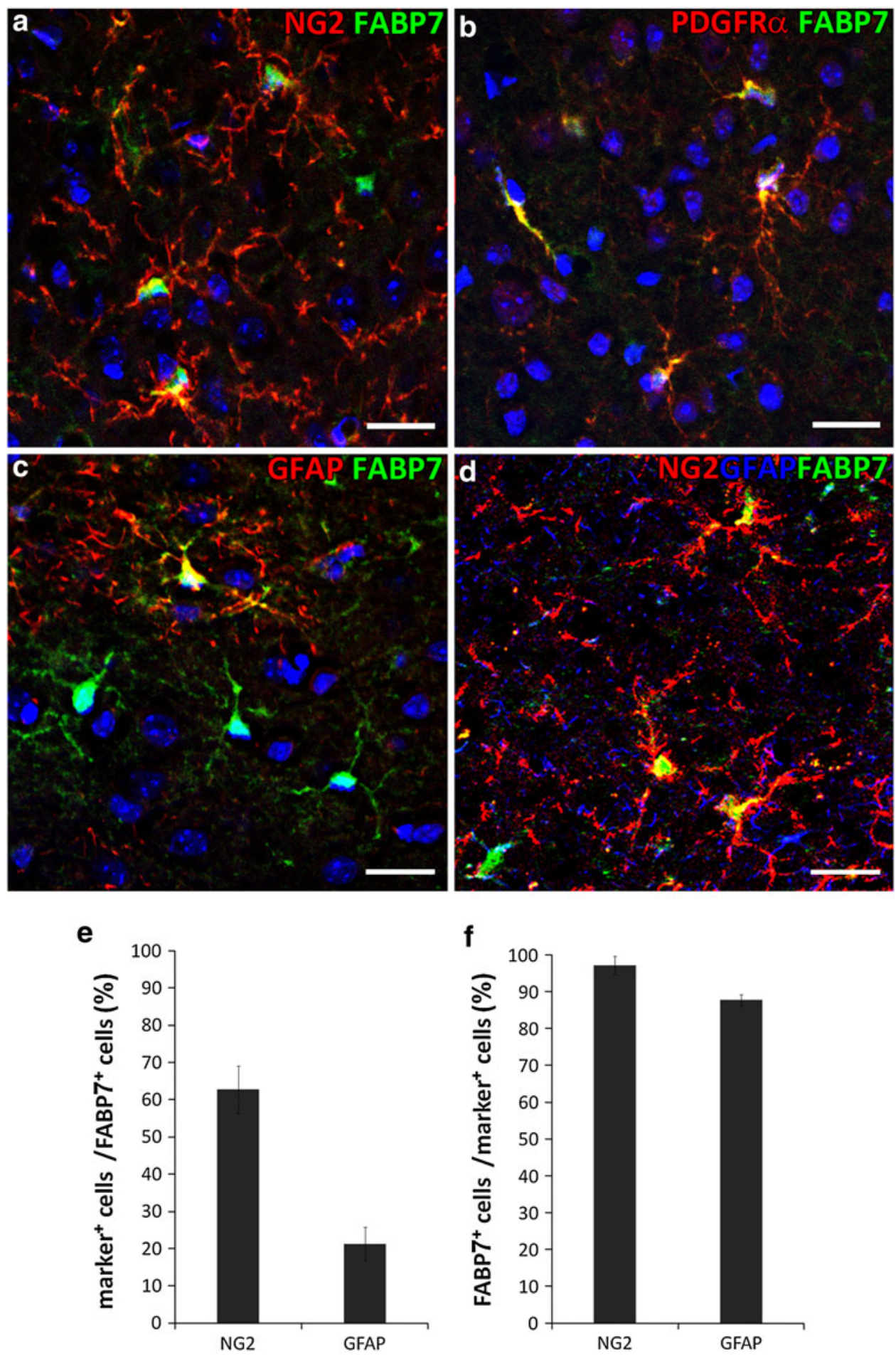

FABP7 was not colocalized with markers for neurons including NeuN (Supplementary Fig. 2a) and MAP2 (Supplementary Fig. 2b), or with makers for microglia including CD11b (Supplementary Fig. 2c). A 60\% of cells immunopositive for Olig2 (a common marker for all oligodendrocyte lineage cells) did not express FABP7 (Supplementary Fig. 2d) suggesting down-regulation of
FABP7 during differentiation of OPCs to oligodendrocytes. We also performed a systematic search in the transcriptome databases of neural cells (Cahoy et al. 2008) and found that the FABP7 gene was statistically enriched in purified astrocytes and OPCs, confirming our results. In the same database, we found reciprocal enrichment of FABP7 in OPCs and FABP5 in oligodendrocytes. 
Taken together, these data suggest that mainly OPCs and astrocytes comprise almost the entire population of FABP7 expressing cells in the intact adult cortex. To our knowledge, this is the first time FABP7 has been shown on OPCs. We also found strong expression of FABP7 on OPCs in primary and secondary OPC cultures (see Supplementary Fig. 3).

\section{Localization of FABP7 in the stab-injured cortex}

To evaluate changes in expression of FABP7 after cortical stab injury, the stab-injured cortices at DPL3 and the contralateral intact cortices were dissected for Western blotting. FABP7 protein expression was significantly increased in the injured cortex compared with the contralateral side (Fig. 2a). When assessed by immunohistochemistry, the population density of $\mathrm{FABP}^{+}$cells significantly increased (approximately 35\%) compared with the intact cortex (Fig. 2b; $28.8 \pm 1.9$ cells at DPL3, $29.1 \pm 1.3$ cells at DPL7 vs. $19.1 \pm 1.4$ cells in the intact cortex: $p<0.05$ and $p<0.01$, respectively) in a $0.1 \mathrm{~mm}^{2}$ area $(0.1 \mathrm{~mm}$ lateral or medial to the edge of injury). In contrast to the intact cortex, the majority of $\mathrm{FABP}^{+}$cells $(80.1 \pm 0.2$ and $82.8 \pm 5.3 \%$ at DPL3 and DPL7, respectively) in the stabinjured cortex were $\mathrm{GFAP}^{+}$(Fig. 2c, g), while almost all GFAP $^{+}$astrocytes $(94.5 \pm 0.8$ and $97.0 \pm 0.01 \%$ at DPL3 and DPL7, respectively) were positive for FABP7 (Fig. 2h). The number of $\mathrm{GFAP}^{+} / \mathrm{FABP}^{+}$cells significantly increased in number in the injured cortex (Fig. 2i; $23.3 \pm 1.7$ cells and $24.4 \pm 0.1$ cells at DPL3 and DPL7, respectively, vs. $4.1 \pm 0.5$ cells in intact cortex in a $0.1 \mathrm{~mm}^{2}$ area), indicating a role for FABP7 in astrocyte proliferation.

A minor proportion of $\mathrm{FABP}^{+}$cells $(35.2 \pm 5.6$ and $29.4 \pm 2.5 \%$ at DPL3 and DPL7, respectively) in the stabinjured cortex co-expressed NG2 (Fig. 2d). The expression of $\mathrm{FABP}^{+} / \mathrm{NG}^{+}$cells in the injured cortex was similar to that in the intact cortex and could be distinguished from $\mathrm{NG} 2^{+}$pericytes in the stab-injured cortex as characterized by their specific elongated morphology and their location around the vessels and close to the injury core. Furthermore, these cells co-expressed PDGFR $\alpha$ (Fig. 2e), indicative of OPCs rather than vascular pericytes.

While the total number of $\mathrm{NG}^{+}$cells significantly increased (approximately 30\%) in the stab-injured cortex compared with the intact cortex $(21 \pm 1.1$ and $19.1 \pm 2.1$ cells/0.1 mm $\mathrm{mm}^{2}$ at DPL3 and DPL7, respectively, vs. $14 \pm$ 1.9 cells $/ 0.1 \mathrm{~mm}^{2}$ in the intact cortex; Supplementary Fig. 4), the total number of $\mathrm{NG}^{+} / \mathrm{FABP}^{+}$cells did not change $\left(10.5 \pm 2.8\right.$ and $9.2 \pm 2.7$ cells $/ 0.1 \mathrm{~mm}^{2}$ at DPL3 and DPL7, respectively, vs. $12.3 \pm 2.2$ cells $/ 0.1 \mathrm{~mm}^{2}$ in the intact cortex; Fig. 2i). Furthermore, the total number of PDGFR $\alpha^{+}$cells did not significantly differ between the intact and injured cortex $(16.4 \pm 0.8$ and $15.9 \pm 4.4$ cells/ $0.1 \mathrm{~mm}^{2}$ at DPL3 and DPL7, respectively, vs. $14 \pm 1.1$ cells $/ 0.1 \mathrm{~mm}^{2}$ in the intact cortex; Supplementary Fig. 4). Similar to the intact cortex, in the stab-injured cortex, FABP7 expression was not seen in neurons positive for MAP2 or NeuN, or in microglia and/or monocyte-derived cells positive for $\mathrm{F} 4 / 80$ or CD11b (data not shown).

Based on these results, localization of $\mathrm{FABP}^{+}$in mainly $\mathrm{NG}^{+}$OPCs in the intact cortex is changed into mainly $\mathrm{GFAP}^{+}$astrocytes in the stab-injured cortex, due to a profound increase in population density of $\mathrm{GFAP}^{+}$ astrocytes. Taken together, these results suggest an association between FABP7 and proliferation of reactive astrocytes after stab injury.

Role of FABP7 in proliferation of astrocytes after stab injury

For further evaluation of the role of FABP7 in proliferation of astrocytes, we examined whether FABP7-deficient astrocytes showed an altered proliferation in response to stab injury. We quantified the number of $\mathrm{BrdU}^{+}$astrocytes and the total population of astrocytes in the cortices of wild-type and FABP7-KO mice after stab injury. BrdU was administered intraperitoneally to wild-type and FABP7-KO mice at 3 days after cortical stab injury, and the number of $\mathrm{BrdU}^{+}$astrocytes was examined immunohistochemically at $2 \mathrm{~h}$ (DPL3; $n=4$ for each genotype) and 4 days (DPL7; $n=4$ for each genotype) after administration (Fig. 3a). In the contralateral side of DPL3 and DPL7 brain cortices, a few cells (1-2 cells per section) were labeled with BrdU, and these were PDGFR $\alpha^{+} / \mathrm{GFAP}^{-}$cells, presumably proliferating OPCs (Fig. 3b).

There were no differences in the total number of $\mathrm{BrdU}^{+}$ cells (including blood derived cells and activated microglia, reactive astrocytes, OPCs, pericytes and/or endothelial cells) between the stab-injured cortex of wild-type and FABP7-KO mice at either time points (Supplementary Fig. 5f). The total number of $\mathrm{BrdU}^{+}$cells increased approximately twofold at DPL7, indicating that some of the cells that were in S-phase at DPL3 proceeded to mitosis or reentered the cell cycle until DPL7. Moreover, it is possible that some cells may have proliferated several times resulting in BrdU levels below the detectable limit.

At DPL3, there was no difference in the total number of $\mathrm{BrdU}^{+} / \mathrm{GFAP}^{+}$cells between wild-type and FABP7-KO mice $\left(8.6 \pm 2\right.$ cells $/ 0.4 \mathrm{~mm}^{2}$ in wild-type vs. $6.3 \pm 3$ cells/ $0.4 \mathrm{~mm}^{2}$ in FABP7-KO) (Fig. 3c, d, i), while at DPL7 there was a significant difference between two groups $\left(29.3 \pm 5.7\right.$ cells $/ 0.4 \mathrm{~mm}^{2}$ in wild-type vs. $18.3 \pm 0.5$ cells $/ 0.4 \mathrm{~mm}^{2}$ in FABP7-KO, $p<0.05$ ) (Fig. 3e, f, i). Consistent with these data, the total number of $\mathrm{GFAP}^{+}$ 

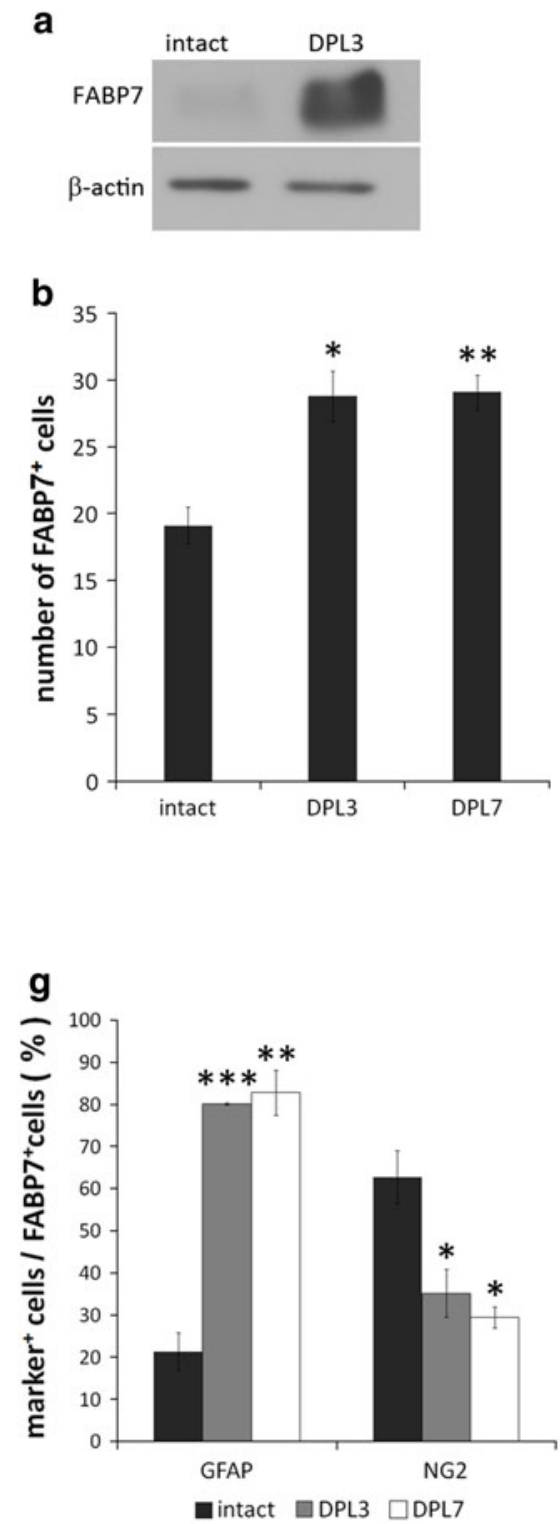
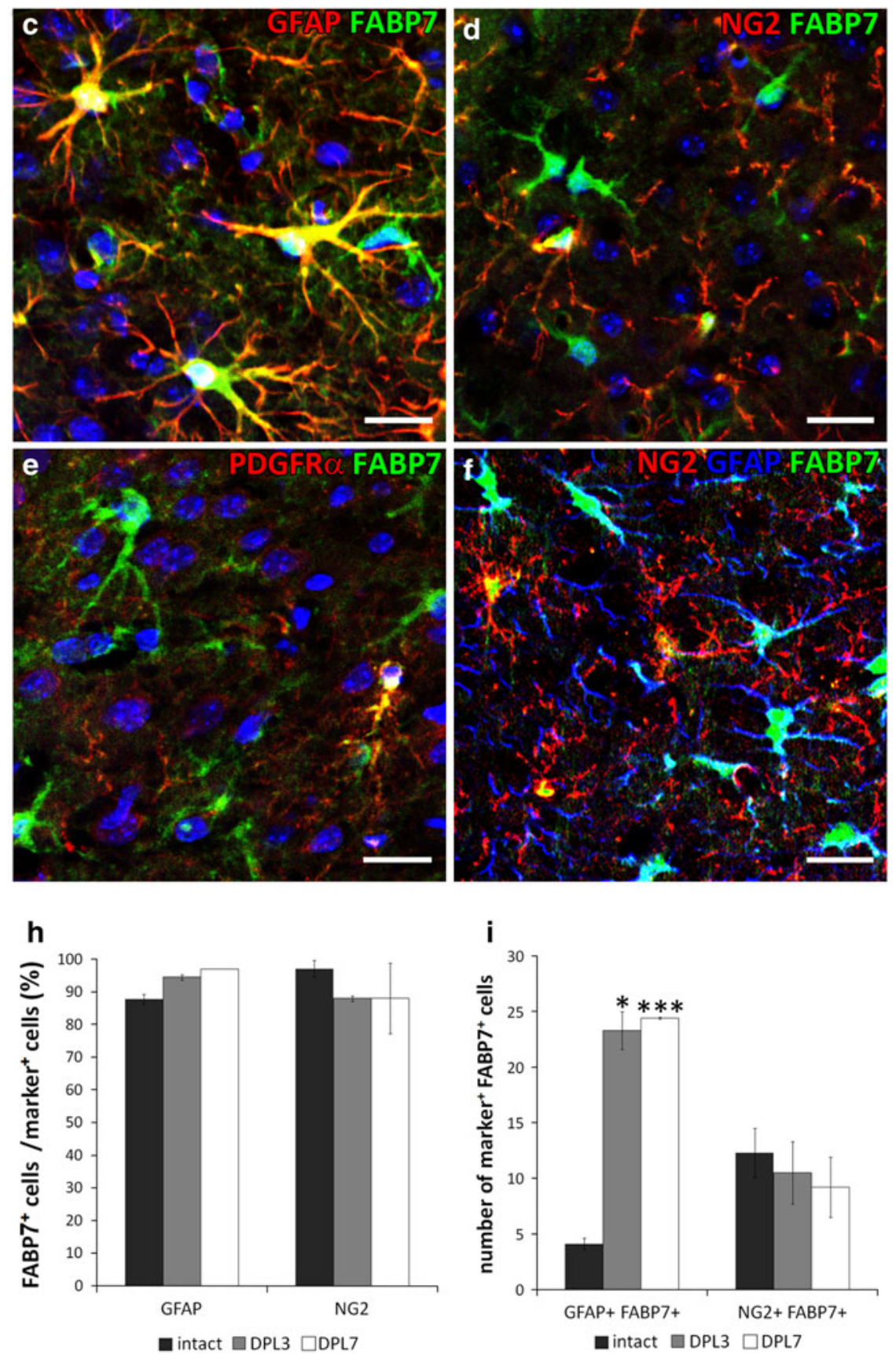

Fig. 2 FABP7 expression in stab-injured cortex. a Western blotting showing increased expression of FABP7 in stab-injured cortex compared with the intact cortex. b Bar graph showing increased population density of $\mathrm{FABP}^{+}$cells in injured cortex compared to intact cortex. c-f Immunofluorescence micrographs showing expression of FABP7 in OPCs and astrocytes after cortical stab injury. c Intensive expression of FABP7 (green) in hypertrophied $\mathrm{GFAP}^{+}$ reactive astrocytes $\left(\right.$ red). d Expression of FABP7 (green) in $\mathrm{NG}^{+}$ OPCs (red). e Expression of FABP7 in OPCs after stab injury confirmed by colocalization of FABP7 (green) and PDGFR $\alpha$ (red).

astrocytes was significantly decreased in FABP7-KO mice at DPL7 (125.7 \pm 7.6 cells $/ 0.4 \mathrm{~mm}^{2}$ in wild-type vs. $106.7 \pm 5.5$ cells $/ 0.4 \mathrm{~mm}^{2}$ in FABP7-KO, $p<0.05$ ) f Localization of FABP7 (green) in $\mathrm{GFAP}^{+}$astrocytes (blue) and $\mathrm{NG}^{+}$OPCs ( red) after stab injury. Note that the majority of FABP7 ${ }^{+}$ cells in stab-injured cortex are astrocytes. g Quantification of astrocytes and $\mathrm{OPCs}$ among $\mathrm{FABP}^{+}$cells in intact and injured cortex. $\mathbf{h}$ Quantification of $\mathrm{FABP}^{+}$cells among astrocytes and OPCs in intact and injured cortex. i Population density of $\mathrm{FABP}^{+} / \mathrm{GFAP}^{+}$ astrocytes and $\mathrm{FABP} 7^{+} / \mathrm{NG}^{+} \mathrm{OPCs}$ in intact and injured cortex. Data in $\mathbf{b}, \mathbf{g}, \mathbf{h}, \mathbf{i}$ are obtained from $0.1 \mathrm{~mm}^{2}$ area. $D P L$ days post lesion. $* p<0.05, * * p<0.01, * * * p<0.001$. Scale bars $20 \mu \mathrm{m}$

(Fig. 3g, Supplementary Fig. 5a-d). The proportion of $\mathrm{BrdU}^{+}$astrocytes among the total astrocyte population also significantly decreased at DPL7 (25.67 $\pm 5.1 \%$ in wild-type 


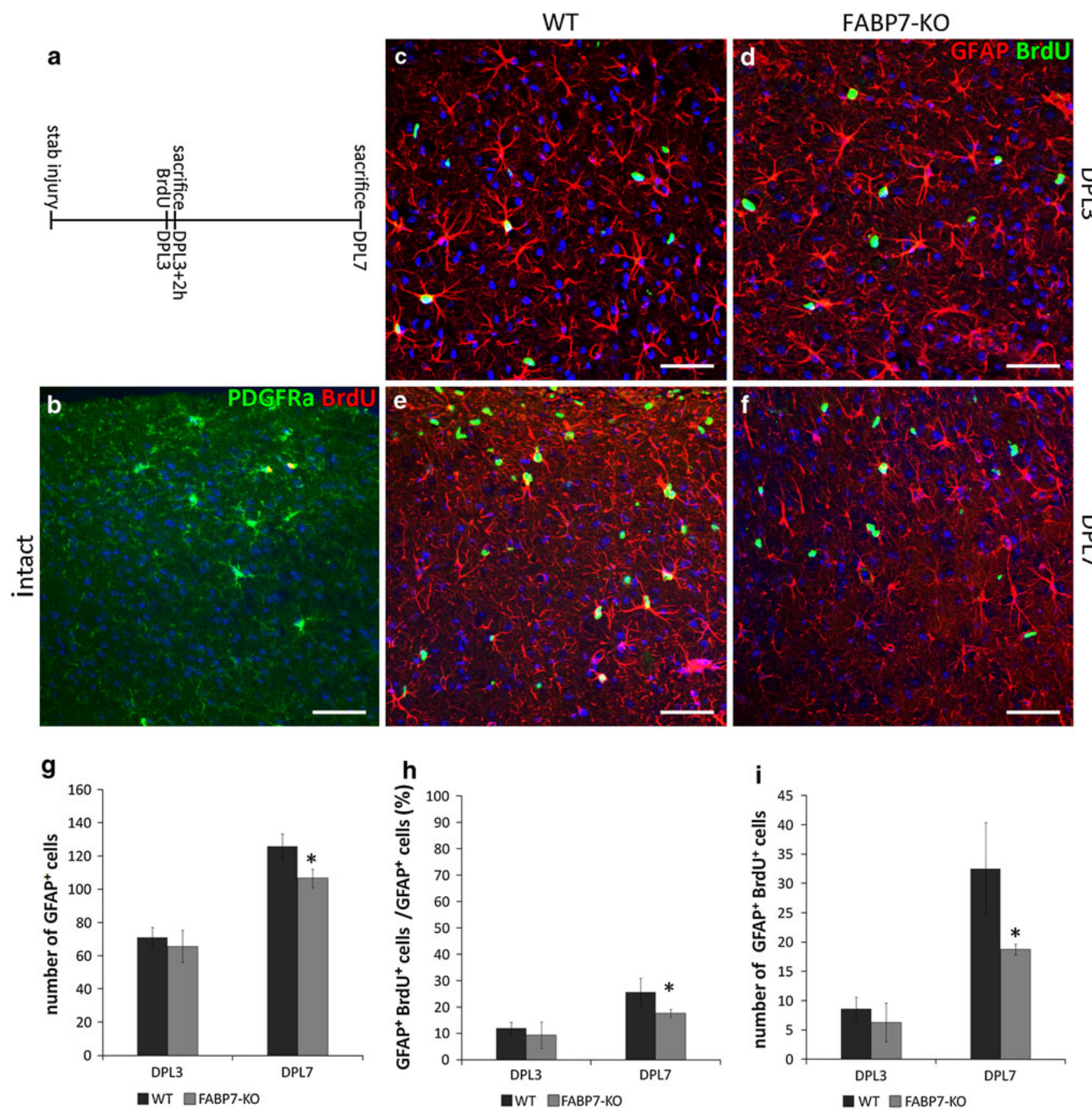

Fig. 3 Decreased proliferation of reactive astrocytes after cortical stab injury in FABP7-KO mice. a BrdU administration paradigm: single injection of BrdU was performed at 3 days after stab injury, and mice were killed $2 \mathrm{~h}$ or 4 days later. b Immunofluorescence micrograph showing that few $\mathrm{BrdU}^{+}$(red) cells were detected in the intact cortex which were PDGFR $\alpha^{+}$(green) OPCs. c-f Representative immunofluorescence micrographs showing $\mathrm{BrdU}^{+}$(green) cells and $\mathrm{GFAP}^{+}$(red) astrocytes in stab-injured cortex in wild-type and FABP7-KO mice at 3 and 7 days after stab injury. Note the lower number of $\mathrm{BrdU}^{+} / \mathrm{GFAP}^{+}$

vs. $17.55 \pm 1.5 \%$ in FABP7-KO, $p<0.05$ ) (Fig. 3h). These data show that astrocyte proliferation is decreased in FABP7-KO after stab injury compared with wild-type, suggesting a role of FABP7 in proliferation of astrocytes. astrocytes in FABP7-KO mice compared with wild-type mice, especially in DPL7. g Bar graph showing the population density of $\mathrm{GFAP}^{+}$astrocytes in the stab-injured cortex of wild-type and FABP7$\mathrm{KO}$ mice. h Bar graph showing the proportion of $\mathrm{BrdU}^{+} / \mathrm{GFAP}^{+}$ astrocytes among total $\mathrm{GFAP}^{+}$astrocytes in the stab-injured cortex of wild-type and FABP7-KO mice. i Bar graph quantifying the population density of $\mathrm{BrdU}^{+} / \mathrm{GFAP}^{+}$astrocytes in stab-injured cortex of wild-type and FABP7-KO mice. Data in $\mathbf{g}, \mathbf{h}$, $\mathbf{i}$ are obtained from $0.4 \mathrm{~mm}^{2}$ area. $D P L$ days post lesion. $* p<0.05$. Scale bars $50 \mu \mathrm{m}$

Role of FABP7 in astrocyte proliferation in vitro

FABP7 was abundantly expressed in primary cultured astrocytes at gene and protein levels (Supplementary Fig. 6a, b), 
and in immunocytochemistry FABP7 was predominantly localized to the cell nuclei of cultured astrocytes (Supplementary Fig. 6c). To study the role of FABP7 in astrocyte proliferation, we examined $\mathrm{BrdU}$ and ${ }^{3} \mathrm{H}$-thymidine incorporation in subconfluent primary cultured astrocytes from wild-type and FABP7-KO mice. The BrdU labeling index (proportion of $\mathrm{BrdU}^{+}$astrocytes among all astrocytes) was significantly decreased (by approximately $30 \%$, $p<0.05)$ in FABP7-KO astrocytes compared with wildtype (Fig. 4a, Supplementary Fig. 7c, d). Similarly, the uptake of ${ }^{3} \mathrm{H}$-thymidine in FABP7-KO astrocytes was significantly decreased (by approximately 20\%, $p<0.05$ ) compared with wild-type (Fig. 4b). Delayed confluency was consistently observed in FABP7-KO astrocytes compared with wild-type (Supplementary Fig. 7a, b). These data further confirm the role of FABP7 in astrocyte proliferation. Next, we transfected FABP7 into NG108 cells, neuroblastoma and glioma hybrid cells, which show no endogenous FABP7 expression (Supplementary Fig. 7e). There was a significant increase in the proliferation of FABP7 transfected cells compared with mock-transfected cells (Supplementary Fig. 7f).

We also evaluated the uptake of $\alpha$-linolenic acid $\left({ }^{18} \mathrm{C}_{3}\right.$, $\mathrm{n}-3)$ and linoleic acid $\left({ }^{18} \mathrm{C}_{2}, \mathrm{n}-6\right)$ in FABP7-KO astrocytes. There was a decrease in incorporation of $\alpha$-linolenic acid $\left({ }^{18} \mathrm{C}_{3}, \mathrm{n}-3\right)$ in FABP7-KO astrocytes $(p<0.05$; Fig. $4 \mathrm{c})$, while no difference was observed in that of linoleic acid $\left({ }^{18} \mathrm{C}_{2}, \mathrm{n}-6\right)$ (Fig. $4 \mathrm{~d}$ ). Taken together, these data suggest that FABP7 is involved in the proliferation of astrocytes by controlling fatty acid homeostasis (metabolism/signal transduction).

\section{Discussion}

FABP7 is abundantly expressed in neural stem cells and radial glia of the developing brain and has been associated with a number of brain diseases including psychotic disorders (Owada et al. 1996; Watanabe et al. 2007; Maekawa et al. 2011) or brain tumors (Godbout et al. 1998; Tso et al. 2006; Liang et al. 2005; Kaloshi et al. 2007). However, the underlying mechanisms of the actions of FABP7 are poorly understood, particularly in the adult brain under normal and pathologic conditions. Herein, we identified FABP7 expressing cells in the adult mouse cortex as both OPCs and astrocytes and found that FABP7 expression was markedly increased in the astrocytes after cortical injury. Furthermore, we examined the phenotype of FABP7-KO mice after cortical stab injury to study the role of FABP7 in gliosis and found that FABP7 played a critical role in regulating astrocyte proliferation in vivo.

Decreased proliferation of reactive astrocytes in FABP7-KO mice is one of the main findings in this study.
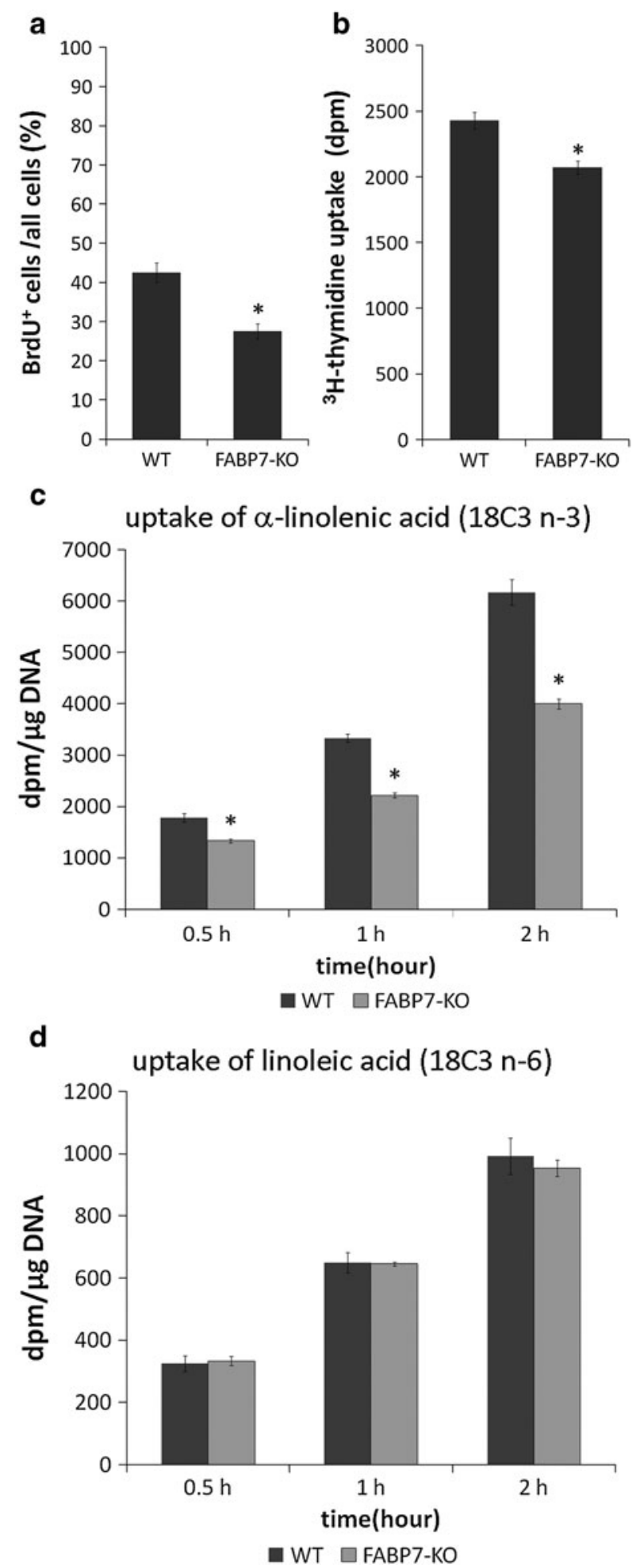

Fig. 4 Decreased proliferation and fatty acid incorporation in primary cultured FABP7-KO astrocytes. a Bar graph showing decreased $\mathrm{BrdU}^{+}$cells at 3 days after passage in FABP7-KO cultured astrocytes compared with wild-type. b Bar graph showing decreased $\mathrm{H}$-thymidine uptake in FABP7-KO cultured astrocytes compared with wild-type astrocytes. Bar graphs showing incorporation of n-3 (c) and n-6 (d) fatty acids in wild-type and FABP7-KO cultured astrocytes. $* p<0.05$ 
We previously reported that FABP7 was substantially expressed by $\mathrm{GFAP}^{+}$astrocytes in the cortex of early postnatal developing brain (Owada et al. 1996), and that the number of $\mathrm{GFAP}^{+}$cells (neural stem cells and early progenitors) and total BrdU uptake were decreased in the hippocampal dentate gyrus of the FABP7-KO mice at postnatal 4 weeks (Watanabe et al. 2007). However, no significant difference in the astrocyte population was detected in the normal adult cortex between wild-type and FABP7-KO mice in this study. One possible explanation is that the cellular demand of fatty acids was developmentally compensated in the FABP7-KO brain by the redundant molecule such as FABP5, another FABP expressed weakly in the astrocytes, while the dramatic increase in the fatty acid requirement for astrocyte proliferation during reactive gliosis, possibly for rapid remodeling of membrane lipid, was not fully covered. Another possibility is that the mechanism by which FABP7 controls astrocyte biology under pathological condition (gliosis process) is partly distinct from that in the normal brain development. However, this study demonstrated that the primary cultured FABP7-KO astrocytes showed the decrease in proliferation and the late confluency, suggesting that FABP7-KO mice may reach to the normal population of astrocytes in the in vivo cortex later than wild-type mice. This hypothesis should be further examined through careful quantification of cortical astrocytes in different developmental stages in FABP7-KO mice.

Primary cultured astrocytes from FABP7-KO mice showed a decrease in proliferation and a decrease in the cellular uptake of $\alpha$-linolenic acid $\left({ }^{18} \mathrm{C}_{3}, n-3\right)$, while there was no decrease in that of linoleic acid $\left({ }^{18} \mathrm{C}_{2}, \mathrm{n}-6\right)$. These data are consistent with the previous finding that FABP7 binds to n-3 PUFAs with high affinity (Balendiran et al. 2000), suggesting that FABP7 is involved in proliferation of astrocytes by controlling fatty acid homeostasis (metabolism/signal transduction). Although the role of n-3 PUFA in the astrocyte proliferation remains unknown, Tian et al. (2011) recently reported that dietary supplementation of the female mice during pregnancy and lactation period with n-3 PUFA results in increased numbers of $\mathrm{GFAP}^{+}$astrocytes and increased expression of PPAR $\gamma$ in the developing brain (Tian et al. 2011). Champeil-Potokar et al. (2004) reported an increased proliferation of primary cultured astrocytes supplemented with DHA by assessing DNA concentration. They also found an increased n-3 PUFAs and DHA composition of membrane phospholipids in astrocytes after supplementation with DHA (Champeil-Potokar et al. 2004). Although the molecular mechanism by which FABP7 regulates astrocyte proliferation remains to be studied, it has been recently shown that transfection of FABP7 in FABP7 ${ }^{-}$ U87 cells (malignant glioma cell line) causes increased expression of growth factors such as FGF2 (Kipp et al.
2011), which is known to promote astrocyte proliferation (Stachowiak et al. 1997; Joy et al. 1997; Gomez-Pinilla et al. 1995). The same group also reported the morphological difference between $\mathrm{FABP}^{+}$and $\mathrm{FABP}^{-}$U87 cells (Mita et al. 2007), in contrast to our not noticing any difference in the morphology of cortical astrocytes in the adult brain (Owada et al. 2006) and in the primary cultured astrocytes between wild-type and FABP7-KO mice. Although the immortalized glioma cells and astrocytes are distinct in their biological characteristics, it is crucial and interesting to measure the expression levels of growth factors in the FABP7-KO astrocytes and further to examine whether decreased proliferation of reactive astrocytes in FABP7-KO mice has any impact on neuronal outcome including neuronal survival and/or regeneration after the brain damage.

We found that the major population of $\mathrm{FABP}^{+}$cells in the adult cortex was OPCs. OPCs are distributed throughout the gray and white matter and are the most prevalent cycling progenitors in the adult CNS (Dawson et al. 2003; Geha et al. 2010; Simon et al. 2011). OPCs are functionally and antigenically distinct from neurons, mature oligodendrocytes, astrocytes and microglia, and as such, are regarded as the fourth major glial population (Nishiyama et al. 2009). Several studies have reported that OPCs generate oligodendrocytes in the developing and mature CNS (Simon et al. 2011; Nishiyama et al. 2009) and that OPCs respond by proliferating, migrating, and differentiating into myelinating oligodendrocytes following demyelination (Levine et al. 2001; Levine and Reynolds 1999; Islam et al. 2009; Franklin 2002; Franklin et al. 2002; Watanabe et al. 2002). We also found that only a subpopulation of oligodendrocyte lineage cells expressed FABP7, suggesting that FABP7 is downregulated during differentiation of OPCs to oligodendrocytes. This finding was confirmed by our analysis of the transcriptome database of isolated neural cells (Cahoy et al. 2008), suggesting a role of FABP7 in OPC differentiation. Failure of OPCs to differentiate into myelinating oligodendrocytes results in failure of spontaneous remyelination, which is important in the pathophysiology of demyelinating disorders such as multiple sclerosis (Chang et al. 2002; Kuhlmann et al. 2008). Of interest, activation of $\operatorname{RXR} \gamma$ was reported to stimulate differentiation of OPCs to enhance remyelination (Huang et al. 2011), while FABPs can regulate gene expression by activation of nuclear receptors such as PPARs and RXRs (Kitajka et al. 2004; Schroeder et al. 2008). There are also several reports addressing the effects of n-3 PUFA on stimulation of the myelinogenesis process (DeWille and Farmer 1992; Martinez and Vazquez 1998; van Meeteren et al. 2006; Salvati et al. 2008). Our transcriptome database search of spontaneous remyelination (Huang et al. 2011) showed that FABP7 is upregulated during remyelination, suggesting a possible role of FABP7 
in the process of OPC differentiation and remyelination. Although the role of FABP7 in OPC biology remains to be elucidated, the confirmation of strong expression of FABP7 in the primary and secondary cultured OPCs in our study suggests an important role and may enable us to do further detailed studies.

In contrast to several previous studies that reported increased number of OPCs after stab injury (Rhodes et al. 2006; Simon et al. 2011; Hampton et al. 2004; Buffo et al. 2005; Levine 1994; McTigue et al. 2001; Alonso 2005), we did not detect any significant changes in OPC numbers between normal and stab-injured cortex. This discrepancy can be partly explained by different sizes of the observation area and its distance from the edge of the injury as well as the different markers used for OPC labeling. Previous reports used mainly NG2 for identification of OPCs, which is also expressed by pericytes and activated microglia, in the injured cortex. In this study, quantification of OPC in the stab-injured cortex was confirmed by using PDGFR $\alpha$ positivities as the most specific marker for OPCs combined with co-expression of NG2 and FABP7. Interestingly, Hampton et al. (2004) showed that the total number of PDGFR $\alpha^{+}$cells remained constant after injury, while the number of $\mathrm{NG}^{+}$cells increased (Hampton et al. 2004). These results were, however, explained by proposing a $\mathrm{NG}^{+} / \mathrm{PDGFR} \alpha^{-}$subpopulation of OPCs, which is not consistent with the current understanding of the antigenic characteristics of OPCs.

Acknowledgments We thank Professor W. Stallcup for the gift of the anti-NG2 and anti-PDGFR $\alpha$ antibodies and his comments, Dr. K Fukunaga for the gift of NG108 cells, Dr. L. Koshy for proof reading, and Dr. T. Tuerxun, Dr. K. Udo, Dr. M. Okuda, Mr. M. Tamechika, Mr. M. Ebrahimi, Mr. Y. Kagawa, Mr. T. Hara, Ms. T. Nakamura and Mr. A. Islam for their technical assistance. This work was supported by grants from Ministry of Education, Culture, Sports, Science and Technology of Japan (no. 21590215) to Y.O., and from the Yamaguchi University Research Project on STRESS.

Open Access This article is distributed under the terms of the Creative Commons Attribution Noncommercial License which permits any noncommercial use, distribution, and reproduction in any medium, provided the original author(s) and source are credited.

\section{References}

Abdelwahab SA, Owada Y, Kitanaka N, Iwasa H, Sakagami H, Kondo $\mathrm{H}$ (2003) Localization of brain-type fatty acid-binding protein in Kupffer cells of mice and its transient decrease in response to lipopolysaccharide. Histochem Cell Biol 119(6):469-475

Alonso G (2005) NG2 proteoglycan-expressing cells of the adult rat brain: possible involvement in the formation of glial scar astrocytes following stab wound. Glia 49(3):318-338

Amminger GP, Schafer MR, Papageorgiou K, Klier CM, Cotton SM, Harrigan SM, Mackinnon A, McGorry PD, Berger GE (2010)
Long-chain omega-3 fatty acids for indicated prevention of psychotic disorders: a randomized, placebo-controlled trial. Arch Gen Psychiatry 67(2):146-154

Arai Y, Funatsu N, Numayama-Tsuruta K, Nomura T, Nakamura S, Osumi N (2005) Role of Fabp7, a downstream gene of Pax6, in the maintenance of neuroepithelial cells during early embryonic development of the rat cortex. J Neurosci 25(42): 9752-9761

Balendiran GK, Schnutgen F, Scapin G, Borchers T, Xhong N, Lim K, Godbout R, Spener F, Sacchettini JC (2000) Crystal structure and thermodynamic analysis of human brain fatty acid-binding protein. J Biol Chem 275(35):27045-27054

Barberger-Gateau P, Letenneur L, Deschamps V, Peres K, Dartigues JF, Renaud S (2002) Fish, meat, and risk of dementia: cohort study. BMJ 325(7370):932-933

Belayev L, Khoutorova L, Atkins KD, Eady TN, Hong S, Lu Y, Obenaus A, Bazan NG (2011) Docosahexaenoic acid therapy of experimental ischemic stroke. Transl Stroke Res 2(1):33-41

Buffo A, Vosko MR, Erturk D, Hamann GF, Jucker M, Rowitch D, Gotz M (2005) Expression pattern of the transcription factor Olig2 in response to brain injuries: implications for neuronal repair. Proc Natl Acad Sci USA 102(50):18183-18188

Cahoy JD, Emery B, Kaushal A, Foo LC, Zamanian JL, Christopherson KS, Xing Y, Lubischer JL, Krieg PA, Krupenko SA, Thompson WJ, Barres BA (2008) A transcriptome database for astrocytes, neurons, and oligodendrocytes: a new resource for understanding brain development and function. J Neurosci 28(1):264-278

Champeil-Potokar G, Denis I, Goustard-Langelier B, Alessandri JM, Guesnet P, Lavialle M (2004) Astrocytes in culture require docosahexaenoic acid to restore the $n-3 / n-6$ polyunsaturated fatty acid balance in their membrane phospholipids. J Neurosci Res 75(1):96-106

Chang A, Tourtellotte WW, Rudick R, Trapp BD (2002) Premyelinating oligodendrocytes in chronic lesions of multiple sclerosis. N Engl J Med 346(3):165-173

Dawson MR, Polito A, Levine JM, Reynolds R (2003) NG2expressing glial progenitor cells: an abundant and widespread population of cycling cells in the adult rat CNS. Mol Cell Neurosci 24(2):476-488

de Lau LM, Bornebroek M, Witteman JC, Hofman A, Koudstaal PJ, Breteler MM (2005) Dietary fatty acids and the risk of Parkinson disease: the Rotterdam study. Neurology 64(12):2040-2045

DeWille JW, Farmer SJ (1992) Postnatal dietary fat influences mRNAS involved in myelination. Dev Neurosci 14(1):61-68

Esparza ML, Sasaki S, Kesteloot H (1995) Nutrition, latitude, and multiple sclerosis mortality: an ecologic study. Am J Epidemiol 142(7):733-737

Fedorova I, Alvheim AR, Hussein N, Salem N Jr (2009) Deficit in prepulse inhibition in mice caused by dietary n-3 fatty acid deficiency. Behav Neurosci 123(6):1218-1225

Franklin RJ (2002) Why does remyelination fail in multiple sclerosis? Nat Rev Neurosci 3(9):705-714

Franklin RJ, Zhao C, Sim FJ (2002) Ageing and CNS remyelination. Neuroreport 13(7):923-928

Gao Q, Lu J, Huo Y, Baby N, Ling EA, Dheen ST (2010) NG2, a member of chondroitin sulfate proteoglycans family mediates the inflammatory response of activated microglia. Neuroscience 165(2):386-394

Geha S, Pallud J, Junier MP, Devaux B, Leonard N, Chassoux F, Chneiweiss H, Daumas-Duport C, Varlet P (2010) NG2 ${ }^{+} /$Olig2 $^{+}$ cells are the major cycle-related cell population of the adult human normal brain. Brain Pathol 20(2):399-411

Godbout R, Bisgrove DA, Shkolny D, Day RS 3rd (1998) Correlation of B-FABP and GFAP expression in malignant glioma. Oncogene 16(15):1955-1962 
Gomez-Pinilla F, Vu L, Cotman CW (1995) Regulation of astrocyte proliferation by FGF-2 and heparan sulfate in vivo. J Neurosci 15(3 Pt 1):2021-2029

Hampton DW, Rhodes KE, Zhao C, Franklin RJ, Fawcett JW (2004) The responses of oligodendrocyte precursor cells, astrocytes and microglia to a cortical stab injury, in the brain. Neuroscience 127(4):813-820

Hedelin M, Lof M, Olsson M, Lewander T, Nilsson B, Hultman CM, Weiderpass E (2010) Dietary intake of fish, omega-3, omega-6 polyunsaturated fatty acids and vitamin $\mathrm{D}$ and the prevalence of psychotic-like symptoms in a cohort of 33,000 women from the general population. BMC Psychiatry 10:38

Huang JK, Jarjour AA, Nait Oumesmar B, Kerninon C, Williams A, Krezel W, Kagechika H, Bauer J, Zhao C, Evercooren AB, Chambon P, Ffrench-Constant C, Franklin RJ (2011) Retinoid X receptor gamma signaling accelerates CNS remyelination. Nat Neurosci 14(1):45-53

Islam MS, Tatsumi K, Okuda H, Shiosaka S, Wanaka A (2009) Olig2expressing progenitor cells preferentially differentiate into oligodendrocytes in cuprizone-induced demyelinated lesions. Neurochem Int 54(3-4):192-198

Joy A, Moffett J, Neary K, Mordechai E, Stachowiak EK, Coons S, Rankin-Shapiro J, Florkiewicz RZ, Stachowiak MK (1997) Nuclear accumulation of FGF-2 is associated with proliferation of human astrocytes and glioma cells. Oncogene 14(2):171-183

Kaloshi G, Mokhtari K, Carpentier C, Taillibert S, Lejeune J, Marie Y, Delattre JY, Godbout R, Sanson M (2007) FABP7 expression in glioblastomas: relation to prognosis, invasion and EGFR status. J Neurooncol 84(3):245-248

Kipp M, Gingele S, Pott F, Clarner T, van der Valk P, Denecke B, Gan L, Siffrin V, Zipp F, Dreher W, Baumgartner W, Pfeifenbring S, Godbout R, Amor S, Beyer C (2011) BLBPexpression in astrocytes during experimental demyelination and in human multiple sclerosis lesions. Brain Behav Immun. doi: 10.1016/j.bbi.2011.05.003

Kitajka K, Sinclair AJ, Weisinger RS, Weisinger HS, Mathai M, Jayasooriya AP, Halver JE, Puskas LG (2004) Effects of dietary omega-3 polyunsaturated fatty acids on brain gene expression. Proc Natl Acad Sci USA 101(30):10931-10936

Kuhlmann T, Miron V, Cui Q, Wegner C, Antel J, Bruck W (2008) Differentiation block of oligodendroglial progenitor cells as a cause for remyelination failure in chronic multiple sclerosis. Brain 131(Pt 7):1749-1758

Lauer K (1994) The risk of multiple sclerosis in the USA in relation to sociogeographic features: a factor-analytic study. J Clin Epidemiol 47(1):43-48

Levine JM (1994) Increased expression of the NG2 chondroitinsulfate proteoglycan after brain injury. J Neurosci 14(8):47164730

Levine JM, Reynolds R (1999) Activation and proliferation of endogenous oligodendrocyte precursor cells during ethidium bromide-induced demyelination. Exp Neurol 160(2):333-347

Levine JM, Reynolds R, Fawcett JW (2001) The oligodendrocyte precursor cell in health and disease. Trends Neurosci 24(1):39-47

Liang Y, Diehn M, Watson N, Bollen AW, Aldape KD, Nicholas MK, Lamborn KR, Berger MS, Botstein D, Brown PO, Israel MA (2005) Gene expression profiling reveals molecularly and clinically distinct subtypes of glioblastoma multiforme. Proc Natl Acad Sci USA 102(16):5814-5819

Maekawa M, Owada Y, Yoshikawa T (2011) Role of polyunsaturated fatty acids and fatty acid binding protein in the pathogenesis of schizophrenia. Curr Pharm Des 17(2):168-175

Martinez M, Vazquez E (1998) MRI evidence that docosahexaenoic acid ethyl ester improves myelination in generalized peroxisomal disorders. Neurology 51(1):26-32
McTigue DM, Wei P, Stokes BT (2001) Proliferation of NG2-positive cells and altered oligodendrocyte numbers in the contused rat spinal cord. J Neurosci 21(10):3392-3400

Mehta LR, Dworkin RH, Schwid SR (2009) Polyunsaturated fatty acids and their potential therapeutic role in multiple sclerosis. Nat Clin Pract Neurol 5(2):82-92

Mita R, Coles JE, Glubrecht DD, Sung R, Sun X, Godbout R (2007) B-FABP-expressing radial glial cells: the malignant glioma cell of origin? Neoplasia 9(9):734-744

Morris MC, Evans DA, Bienias JL, Tangney CC, Bennett DA, Wilson RS, Aggarwal N, Schneider J (2003) Consumption of fish and n-3 fatty acids and risk of incident Alzheimer disease. Arch Neurol 60(7):940-946

Muskiet FA, Kemperman RF (2006) Folate and long-chain polyunsaturated fatty acids in psychiatric disease. J Nutr Biochem 17(11):717-727

Nag S (2011) Morphology and properties of astrocytes. Methods Mol Biol 686:69-100

Nishiyama A, Komitova M, Suzuki R, Zhu X (2009) Polydendrocytes (NG2 cells): multifunctional cells with lineage plasticity. Nat Rev Neurosci 10(1):9-22

Nishiyama A, Suzuki R, Zuo H, Zuo X (2010) Oligodendrocyte progenitor cell culture. In: Doering LC (ed) Protocols for neural cell culture, 4th edn. Humana Press, New York, pp 217-230

Nordvik I, Myhr KM, Nyland H, Bjerve KS (2000) Effect of dietary advice and $n-3$ supplementation in newly diagnosed MS patients. Acta Neurol Scand 102(3):143-149

Owada Y, Yoshimoto T, Kondo H (1996) Spatio-temporally differential expression of genes for three members of fatty acid binding proteins in developing and mature rat brains. J Chem Neuroanat 12(2):113-122

Owada Y, Abdelwahab SA, Kitanaka N, Sakagami H, Takano H, Sugitani Y, Sugawara M, Kawashima H, Kiso Y, Mobarakeh JI, Yanai K, Kaneko K, Sasaki H, Kato H, Saino-Saito S, Matsumoto N, Akaike N, Noda T, Kondo H (2006) Altered emotional behavioral responses in mice lacking brain-type fatty acid-binding protein gene. Eur J Neurosci 24(1):175-187

Ozerdem U, Grako KA, Dahlin-Huppe K, Monosov E, Stallcup WB (2001) NG2 proteoglycan is expressed exclusively by mural cells during vascular morphogenesis. Dev Dyn 222(2):218-227

Peet M, Brind J, Ramchand CN, Shah S, Vankar GK (2001) Two double-blind placebo-controlled pilot studies of eicosapentaenoic acid in the treatment of schizophrenia. Schizophr Res 49(3):243-251

Rhodes KE, Raivich G, Fawcett JW (2006) The injury response of oligodendrocyte precursor cells is induced by platelets, macrophages and inflammation-associated cytokines. Neuroscience 140(1):87-100

Ross BM, Seguin J, Sieswerda LE (2007) Omega-3 fatty acids as treatments for mental illness: which disorder and which fatty acid? Lipids Health Dis 6:21

Salvati S, Natali F, Attorri L, Di Benedetto R, Leonardi F, Di Biase A, Ferri F, Fortuna S, Lorenzini P, Sanchez M, Ricceri L, Vitelli L (2008) Eicosapentaenoic acid stimulates the expression of myelin proteins in rat brain. J Neurosci Res 86(4):776-784

Schroeder F, Petrescu AD, Huang H, Atshaves BP, McIntosh AL, Martin GG, Hostetler HA, Vespa A, Landrock D, Landrock KK, Payne HR, Kier AB (2008) Role of fatty acid binding proteins and long chain fatty acids in modulating nuclear receptors and gene transcription. Lipids 43(1):1-17

Simon C, Gotz M, Dimou L (2011) Progenitors in the adult cerebral cortex: cell cycle properties and regulation by physiological stimuli and injury. Glia 59(6):869-881

Stachowiak MK, Moffett J, Maher P, Tucholski J, Stachowiak EK (1997) Growth factor regulation of cell growth and proliferation 
in the nervous system. A new intracrine nuclear mechanism. Mol Neurobiol 15(3):257-283

Swank RL, Lerstad O, Strom A, Backer J (1952) Multiple sclerosis in rural Norway its geographic and occupational incidence in relation to nutrition. N Engl J Med 246(19):722-728

Tian C, Fan C, Liu X, Xu F, Qi K (2011) Brain histological changes in young mice submitted to diets with different ratios of $n-6 / n-3$ polyunsaturated fatty acids during maternal pregnancy and lactation. Clin Nutr. doi:10.1016/j.clnu.2011.03.002

Tso CL, Shintaku P, Chen J, Liu Q, Liu J, Chen Z, Yoshimoto K, Mischel PS, Cloughesy TF, Liau LM, Nelson SF (2006) Primary glioblastomas express mesenchymal stem-like properties. Mol Cancer Res 4(9):607-619

van Meeteren ME, Baron W, Beermann C, Dijkstra CD, van Tol EA (2006) Polyunsaturated fatty acid supplementation stimulates differentiation of oligodendroglia cells. Dev Neurosci 28(3): 196-208

Watanabe M, Toyama Y, Nishiyama A (2002) Differentiation of proliferated NG2-positive glial progenitor cells in a remyelinating lesion. J Neurosci Res 69(6):826-836

Watanabe A, Toyota T, Owada Y, Hayashi T, Iwayama Y, Matsumata M, Ishitsuka Y, Nakaya A, Maekawa M, Ohnishi T, Arai R,
Sakurai K, Yamada K, Kondo H, Hashimoto K, Osumi N, Yoshikawa T (2007) Fabp7 maps to a quantitative trait locus for a schizophrenia endophenotype. PLoS Biol 5(11):e297

Weinstock-Guttman B, Baier M, Park Y, Feichter J, Lee-Kwen P, Gallagher E, Venkatraman J, Meksawan K, Deinehert S, Pendergast D, Awad AB, Ramanathan M, Munschauer F, Rudick R (2005) Low fat dietary intervention with omega-3 fatty acid supplementation in multiple sclerosis patients. Prostaglandins Leukot Essent Fatty Acids 73(5):397-404

White BD, Nathe RJ, Maris DO, Nguyen NK, Goodson JM, Moon RT, Horner PJ (2010) Beta-catenin signaling increases in proliferating $\mathrm{NG}_{2}^{+}$progenitors and astrocytes during posttraumatic gliogenesis in the adult brain. Stem Cells 28(2):297307

Yang H, Cheng XP, Li JW, Yao Q, Ju G (2009) De-differentiation response of cultured astrocytes to injury induced by scratch or conditioned culture medium of scratch-insulted astrocytes. Cell Mol Neurobiol 29(4):455-473

Zhu L, Lu J, Tay SS, Jiang H, He BP (2010) Induced NG2 expressing microglia in the facial motor nucleus after facial nerve axotomy. Neuroscience 166(3):842-851 